\title{
Good Knowledge of COVID-19 Increased Preventive Behavior on Last Year Undergraduate Medical Students at University of Jember, East Java, Indonesia
}

\author{
Raghda Gita Safitri, Ancah Caesarina Novi Marchianti, Laksmi Indreswari
}

Faculty of Medicine, University of Jember, Indonesia

\section{ABSTRACT}

Background: Indonesia is in first place in ASEAN regarding the high number of confirmed cases and deaths of Covid-19 on November 9, 2020. This can be caused by a lack of preventive behavior related to Covid-19, one of which is influenced by knowledge. The purpose of this study was to determine the relationship between knowledge level of Covid-19 and Covid-19 preventive behavior in last year undergraduate medical students at University of Jember.

Subjects and Method: A cross sectional study was conducted online through a questionnaire that will be distributed using Google form in May 2021. A total of 121 last year undergraduate medical students at University of Jember were enrolled using a total sampling technique. The dependent variable is level of knowledge related to Covid-19 and the independent variable is Covid19 preventive behavior. The data obtained through Google form will be analyzed using the SPSS version 26.0 application and using the Spearman Rho Correlation method.

Results: Based on univariate analytic, $97.5 \%$ students have a good knowledge and $90.9 \%$ students perform high preventive behavior of Covid-19. Bivariate analytic by testing correlation between one's knowledge of Covid-19 and the preventive behavior obtained $\mathrm{p}<0.001$ correlation coefficient of 0.504 .

Conclusion: The good knowledge of Covid-19 increased preventive behavior on last year undergraduate medical students at University of Jember.

Keywords: Physical distancing, Covid-19, online questionnaire.

\section{Correspondence:}

Ancah Caesarina Novi Marchianti. Faculty of Medicine, University of Jember. Jl. Kalimantan Tegalboto 37, Jember, East Java, Indonesia. Email: ancah@unej.ac.id. Mobile Phone:+62331337877.

\section{Cite this as:}

Safitri RG, Marchianti ACN, Indreswari L (2021). The Good Knowledge of COVID-19 Increased Preventive Behavior on Last Year Undergraduate Medical Students at University of Jember. J Health Promot Behav. 06(02): 97-103. https://doi.org/10.26911/thejhpb.2021.06.02.02.

cC) (1) (2) Journal of Health Promotion and Behavior is licensed under a Creative Commons

EY NC SA Attribution-Non Commercial-Share Alike 4.o International License.

\section{BACKGROUND}

It was found 41 cases of pneumonia of unknown cause in Wuhan, China's Hubei Province at the end of 2019 (Lu et al., 2020). This disease called Covid-19 on February 11, 2020 (World Health Organization, 2020). Indonesia ranks first in ASEAN regarding the high number of confirmed cases and deaths of Covid-19 on November 9, 2020 (ASEAN, 2020). This shows that the Covid-19 pandemic is not over and cannot be controlled.

One form of preventive behavior recommended by WHO is to implement physical distancing, maintaining a physical distance of at least 1 meter and avoiding gathering in crowds (Widyaningrum et al., 2020). The Indonesian government has issued regulations to reduce the number of 
cases of Covid-19 during this pandemic such as school and work done from home (online), prohibiting mass gathering activities, and limiting operating hours for certain places. However, the problem that arises is that most Indonesians have not complied with the regulations issued by the Indonesian government, such as taking vacations to various places and then returning to their hometowns. This can be caused by a lack of knowledge and attention regarding the prevention of Covid-19 (Yanti et al., 2020). Knowledge influence behavior because knowledge makes behavior last longer than behavior that is not based on knowledge (Notoatmodjo, 2012).

Jember is one of the areas in East Java that has a high incidence of Covid-19, 1440 confirmed cases and 57 deaths on November 9 (Pemerintah Provinsi Jatim, 2020). The last year undergraduate medical students at University of Jember will soon enter the clinical year and will also be the first to come into contact with Covid-19 in the hospital, so last year undergraduate medical students at University of Jember must have good knowledge about Covid-19 before entering the clinical year, including knowledge about the manifestations of the disease. clinical features, routes of disease transmission, risk factors, and prevention of Covid-19 (Taghrir et al., 2020). With good knowledge, last year undergraduate medical students at University of Jember can make an early diagnosis and are better able to take preventive measures so that they can protect themselves from the risk of Covid-19 transmission when entering the clinical year. This is in accordance with research conducted at the Central Surgical Installation of Dr. Kariadi Hospital Semarang which states that there is a significant relationship between knowledge related to prevention and preventive behavior (Khoidrudin et al., 2011).

Based on the background that has been stated, researchers are interested in examining the relationship between knowledge level related to Covid-19 and Covid-19 prevention behavior in last year undergraduate medical students at University of Jember.

\section{SUBJECTS AND METHOD}

\section{Study Design}

This research used an analytical research type with a cross section study approach, because the data collection is carried out at one time simultaneously. This research was conducted in March 2021 by filling out an online questionnaire without making physical contact or face-to-face contact according to the Covid-19 prevention protocol.

\section{Population and Sample}

The population in this study were last year undergraduate medical students at University of Jember who were willing to be research subjects and signed the Informed Consent. The sampling technique in this study was using total sampling so that the sample size in the research was 121 people.

\section{Study Variables}

The dependent variable was level of knowledge related to Covid-19 and the independent variable was Covid-19 preventive behavior.

\section{Operational Definition of Variables}

Covid-19 is a process of knowing objects through the senses they have, the eyes, ears, nose, tongue, and skin, in this case is the process of knowing which includes symptoms, transmission, incubation period, diagnosis, and prevention of Covid -19

Covid-19 prevention behavior is an activity carried out by a person with the aim of maintaining health by preventing the 
transmission of Covid-19 in this pandemic era, both activities that can be observed as well as activities that cannot be observed.

\section{Study Instruments}

The research instrument was a questionnaire distributed online via google form and has been tested for validity and reliability. The link for the google form is distributed through a group on whatsapp containing research samples and researchers.

\section{Data Analysis}

The analysis in this study used the SPSS version 26.0 application in univariate and bivariate ways. Univariate analysis was carried out on each variable by presented it in the form of percentages and distributions

Table 1. Univariate Analysis (categorical data) of knowledge level of Covid-19 and Covid-19 preventive behavior

\begin{tabular}{llll}
\hline Characteristic & Category & Frequency & Percentage \\
\hline \multirow{2}{*}{ Knowledge level of Covid-19 } & Good & 118 & $97.5 \%$ \\
& Moderate & 3 & $2.5 \%$ \\
\multirow{2}{*}{ Covid-19 preventive behavior } & Low & O & $0 \%$ \\
& Ligh & 110 & $90.9 \%$ \\
\hline
\end{tabular}

Table 1 showed the distribution of knowledge levels related to Covid-19 was 118 students (97.5\%) had good knowledge, 3 students (2.5\%) had moderate knowledge, and no student had poor knowledge (o\%). In this study, the distribution of Covid-19 prevention behavior was that 110 students without the need to draw conclusions. Bivariate analysis using the Spearman Rho correlation method.

\section{Research Ethic}

The ethical feasibility in this study has been published by the Ethics Commission of the Faculty of Medicine, University of Jember with the number 1.486/H25.1.11/KE/2O21 on March 3, 2021.

\section{Univariate analysis}

Univariate analysis included knowledge level of Covid-19 and Covid-19 preventive behavior.

Table 2. Bivariate analysis of knowledge level of Covid-19 with Covid-19 preventive behavior (an analysis by Spearman Rho)

\begin{tabular}{|c|c|c|c|c|c|c|}
\hline \multirow{3}{*}{$\begin{array}{c}\text { Knowledge level of } \\
\text { Covid-19 }\end{array}$} & \multicolumn{4}{|c|}{ Covid-19 preventive behavior } & \multirow{3}{*}{$\mathbf{r}$} & \multirow{3}{*}{$\mathbf{p}$} \\
\hline & \multicolumn{2}{|c|}{ High } & \multicolumn{2}{|c|}{ Low } & & \\
\hline & $\mathbf{N}$ & $\%$ & $\mathbf{N}$ & $\%$ & & \\
\hline Good & 110 & $93.2 \%$ & 8 & $6.8 \%$ & $0-0$ & $<0001$ \\
\hline Moderate & o & $0 \%$ & 3 & $100 \%$ & 0.50 & $<0.001$ \\
\hline
\end{tabular}

Table 2 showed that 118 students (100\%) had a good level of knowledge, with 110 students (93.2\%) had high preventive behavior and 8 people (6.8\%) had low

preventive behavior. There are 3 students
(90.9\%) had good preventive behavior and 11 students (9.1\%) had poor preventive behavior.

\section{Bivariate analysis}

Bivariate analysis used to see the correlation between knowledge level of Covid-19 with Covid-19 preventive behavior. who have moderate knowledge and all of them have low preventive behavior (100\%). There are no students who have a low level of knowledge (o\%). 
Spearman Rho test results obtained $\mathrm{p}$ $<0.001$ which means that there is a significant relationship between the level of knowledge related to Covid-19 with Covid19 preventive behavior. The correlation coefficient value is 0.504 which means that there is a moderate relationship between the level of knowledge related to Covid-19 with Covid-19 preventive behavior.

\section{DISCUSSION}

The results of this study are corresponding with research that explains that there is a significant relationship between the level of knowledge related to Covid-19 and Covid19 preventive behavior. This can be seen from the $\mathrm{p}$ value which shows 0.015 and the correlation strength value or r-value is 0.178 which means that there is a very weak relationship between the independent variable and the dependent variable (Ramadhani and Nuryani, 2020). There is study that support this study, which mention that there is a significant relationship between the level of knowledge related to Covid-19 and the habit of using masks in Ngronggah community which is a form of Covid-19 preventive behavior with a p-value of 0.004 (Sari et al., 2020). Knowledge related to Covid-19 is important for the creation of a Covid-19 preventive behavior (Siddiqui et al., 2020). Before a person can implement preventive behavior, the person will first receive a stimulus in the form of information related to symptoms, transmission, incubation period, diagnosis, and prevention. Then the stimulus will be processed into new knowledge that will foster a closed reaction, that is an attitude towards information related to Covid-19. However, attitudes towards information related to Covid-19 will not necessarily manifest into Covid-19 prevention behavior if there are no supporting factors. If there are supporting factors, then the attitude towards infor- mation related to Covid-19 will be an action or behavior to prevent Covid-19 which is included in open behavior (Notoatmodjo, 2012).

The respondents of this study, the last year undergraduate medical students at University of Jember, who have a high level of knowledge related to Covid-19 is 118 students or $97.5 \%$ of the total sample. This shows that many last year undergraduate medical students at University of Jember are highly knowledgeable. These results are in corresponding with previous research which stated that students who had a medical education background in China had a high level of knowledge related to Covid-19 (Gao et al., 2020). A similar study also stated that $51.35 \%$ of health students had good knowledge regarding Covid-19 (Sukesih et al., 2020). The underlying reason for this is that students who have a medical education background, in this case students of the Faculty of Medicine, are more aware of knowing about Covid-19, so they find out more about Covid-19 from various sources (Aziz and Garini, 2020). Sources that are often used to get information related to COVID-19 are social media (89.1\%) and television (69.5\%) (Mustafa et al., 2020).

The number of respondents who have high preventive behavior is $90.9 \%$. This shows that many last year undergraduate medical students at University of Jember are implementing well preventive behavior. These results are in line with previous study in Gorontalo which stated that the Covid-19 prevention behavior in students was high (Ramadhani and Nuryani, 2020). Another study that supports these results states that as many as $55.9 \%$ of students have implemented social distancing behavior during the Covid-19 pandemic as a form of Covid19 prevention behavior (Syadidurrahmah et al., 2020). The preventive behavior recom- 
mended by the Indonesian Ministry of Health is to use masks or PPE, wash hands, apply cough and sneeze etiquette, and seek treatment immediately if experiencing symptoms of Covid-19 (Kemenkes RI, 2020). In addition, avoiding crowds such as avoiding going to restaurants, mall, and cinemas can also reduce the incidence of Covid-19 (Galvin et al., 2020)

The limitations in this study that this research was conducted without meeting face to face or through google form because it prevents the transmission of Covid-19. So that in the next research, it can be done face-to-face by implementing Covid-19 preventive protocols such as using masks, physical distancing, and washing hands after doing activities. Moreover, if there are still concerns, it can be done using a video communication application.

Based on the analysis results of the research that has been carried out, it can be concluded that there is a match between the existing theory and the research that states respondents who have a good level of knowledge related to Covid-19 will have high Covid-19 preventive behavior. This shows that behavior is influenced by knowledge, because knowledge makes behavior last longer than behavior that is not based on knowledge (Notoatmodjo, 2014).

\section{AUTHOR CONTRIBUTION}

Raghda Gita Safitri acts as the main author who carries out all stages of research and completion of research papers. Ancah Caesarina Novi Marchianti and Laksmi Indreswari plays a role in developing research designs, ideas, and providing suggestions for research

\section{CONFLICT OF INTEREST}

There is no conflict of interest.
FUNDING AND SPONSORSHIP

This research is self-funded.

\section{ACKNOWLEDGEMENT}

The authors gratitude goes to Medical Faculty of University of Jember especially the last year undergraduate students who have helped and are willing to participate in this research as the research subject.

\section{REFERENCE}

ASEAN (2020) The Coronavirus in Asia and ASEAN - Live Updates by Country. Available at: https://www.aseanbriefing.com/news/coronavirus-asia-asean-live-updates-by-country/\#aseancoronavirusupdatesliveupdatesbycountryHeader (Accessed: November 9, 2020).

Aziz M, Garini PW. (2020). The association between knowledge and attitude towards covid-19 and interest in online lecture of pre-clinic and clinic secretariat students of faculty of medicine, Majalah Kedokteran Sriwijaya, $52(4)$.

Dahlan MS (2015). Statistik untuk Kedokteran dan Kesehatan:Deskriptif, Bivariat, dan Multivariat. Jakarta: Epidemiologi Indonesia.

Galvin CJ, Li YC (Jack), Malwade S and Syed-Abdul S (2020). COVID-19 Preventive Measures Showing an Unintended Decline in Infectious Diseases in Taiwan. International Journal of Infectious Diseases, 98, pp: 18-20. doi: 10.1016/j.ijid.2020.06.062.

Gao Z, Ying S, Liu J, Zhang H, Li J, Ma C. (2020). A cross-sectional study: Comparing the attitude and knowledge of medical and non-medical students toward 2019 novel coronavirus. Journal of infection and public health, 13(10), 14191423. https://doi.org/10.1016/j.jiph.2020.06.031 
Khoidrudin A, Pohan VY, Riwayati (2011). Faktor-faktor yang mempengaruhi perilaku perawat dalam menerapkan prosedur tindakan pencegahan universal Di IBS RSUP Dr. Kariadi Semarang. Jurnal Keperawatan FIKKes. 4(1): 1-18.

Lu H, Stratton CW, Tang, YW (2020). Outbreak of pneumonia of unknown etiology in Wuhan, China: The mystery and the miracle," Journal of Medical Virology, 92, pp. 401-402. doi: $10.1002 / j m v .25678$.

Mustafa RM, Alrabadi NN, Alshali RZ, Khader YS, Ahmad DM (2020). Knowledge, Attitude, Behavior, and Stress Related to COVID-19 among Undergraduate Health Care Students in Jordan. European journal of dentistry, 14(So1),S50-S55. https://doi.org/10.1055/s-0040-1719212

Pemerintah Provinsi Jatim (2020) Peta Sebaran COVID-19 Jatim. Available at: http://infocovid19.jatimprov.go.id/ (Accessed: June 28, 2020).

Ramadhani F, Nuryani (2020) Pengetahuan Berkorelasi Positif dengan Perilaku Pencegahan COVID - 19 pada Mahasiswa di Gorontalo. Jurnal Ilmiah Kesehatan (JIKA), 2(3): 108-117.

Kemenkes RI (2020). Pedoman Kesiapsiagaan Menghadapi Infeksi COVID19," Kementrian Kesehatan Republik Indonesia. Available at: https://www.kemkes.go.id/resources/download/in fo-terkini/Coronavirus/DOKUMEN-

_RESMI_Pedoman_Kesiapsiagaan_n CoV_Indonesia_28 Jan 2020.pdf.

Sari DP, Sholihah N, Atiqoh (2020). Hubungan Antara Pengetahuan Masyarakat dengan Kepatuhan Penggunaan Masker Sebagai Upaya Pencegahan COVID-19 di Ngronggah," INFOKES Journal, 10(1), pp. 52-5. Available at: http://ojs.udb.ac.id/index.php/infoke s/article/view/850.

Siddiqui, AA, Alshammary F, Amin J, Rathore HA, Hassan I, Ilyas M, Alam MK (2020). Knowledge and practice regarding prevention of COVID-19 among the Saudi Arabian population. Work (Reading Mass), 66(4), 767775. https://doi.org/10.3233/WOR203223.

Sukesih et al. (2020). Pengetahuan dan sikap mahasiswa kesehatan tentang pencegahan covid-19 di Indonesia. Jurnal Ilmu Keperawatan dan Kebidanan, 11(2): 258-264.

Syadidurrahmah F, Muntahaya F, Islamiyah SZ, Fitriani TA, Nisa H (2020). Perilaku Physical Distancing Mahasiswa UIN Syarif Hidayatullah Jakarta pada Masa Pandemi COVID-19, Perilaku dan Promosi Kesehatan: Indones J Health Promot Behav. 2(1): 29. doi: 10.47034/ppk.v2i1.4004.

Taghrir MH, Borazjani R, Shiraly R (2020). COVID-19 and Iranian Medical Students; A Survey on Their RelatedKnowledge, Preventive Behaviors and Risk Perception. Archives of Iranian medicine, 23(4): 249-254. https://doi.org/10.34172/aim.2020.06.

Widyaningrum N, Putri DY, Wilopo (2020). Gambaran Penerapan Physical Distacing Sebagai Upaya Menekan Persebaran Covid-19 Di Provinsi Daerah Istimewa Yogyakarta 1.NUSANTARA: Jurnal Ilmu Pengetahuan Sosial, 7(2): 470-481. Http://dx.doi.org/10.31604/jips.v7i2.020.470-481.

World Health Organization (2020) WHO Director-General's remarks at the media briefing on 2019-nCoV on 11 February 2020. Available at: https://www.who.int/dg/speeches/detail/wh o-director-general-s-remarks-at-themedia-briefing-on-2019-ncov-on-11february-2020 (Accessed: June 28, 
Safitri et al./ Good Knowledge of COVID-19 Increased Preventive Behavior

2020).

Yanti B, Mulyadi E, Wahiddun, Novika $\mathrm{RGH}$, Arina YMD, Martani NS, Nawan (2020). Community Knowledge, attitudes, and behavior towards social distancing policy as prevention transmission of Covid-19 in Indonesia. Jurnal Administrasi Kesehatan Indonesia, 8(1): 4. doi: 10.20473/jaki.v8i2.2020.4-14. 